\section{Lead-free fuel on sale by 1989}

\section{Brussels}

AlThOUGH European Community environment ministers meeting in Brussels on 6 December agreed to introduce lead-free petrol in the Community from 1 October 1989 , the decision to phase out lead from petrol may cause friction between countries keen to introduce controls and those less concerned about lead pollution. The directive seeks to avoid confrontation with West Germany, which said in September that it would start selling leadfree petrol from 1986 .

At the end of a marathon session, ministers had agreed to make a single grade of "super-petrol"' widely available in the Community on a mandatory basis from 1989, while at the same time leaving member states free to introduce the leadfree variety any time between now and then. The European Parliament's environment committee had recommended the introduction of lead-free petrol by 1986 .

West Germany also plans to speed up the phasing out of normal leaded petrol, but a unilateral move will require prior consent of the European Commission and the other member states.

Although lead-free petrol will be on sale from 1989, the agreement reached by ministers does not include any incentives to encourage motorists to use lead-free petrol, in spite of recommendations by consumer groups in a Community report published in April 1984.

The only "technical" constraint to use lead-free petrol would be if cars were to be fitted with catalytic converters in order to conform with stricter vehicle emission standards. But ministers made little progress on the Commission's proposal to reduce vehicle emissions (carbon monoxide, nitrous oxides and hydrocarbons) to US standards and a decision on the matter has been postponed until the next Environment Council, scheduled for the end of January 1985.

In the meantime, proposals will be prepared for emission standards to be laid down according to the different categories of cars. It is likely that they will suggest the strictest standards for 2-litre models and over, which represent 10 per cent of cars on European roads, while cars under 1.3 litres might escape controls altogether. The idea of different categories does not, however, appeal to the West Germans, who are sticking to their decision to make antipollution devices obligatory on a national scale in 1988 and 1989.

The West German decision means that three-way or oxidation catalytic converters will soon be essential to all cars sold there. But countries that produce mainly small and medium-sized cars, such as France and Italy, are reticent in view of the high cost involved, preferring to wait for lean-burn engine technology which could make its debut in Europe in two years' time.

A more immediate solution to curb emissions is to introduce stricter speed limits. The proposal put forward by French environment minister Huguette Bouchardeau, however, was not welcomed by West Germany, where speed on the autobahns is unrestricted.

On the other hand, pressure from the French was largely responsible for the watering down of the commitments made in June to limit the lead content of leaded petrol (which will be sold in parallel during the transition period for cars built before 1989) to 0.15 grams per litre. The French complained that the reduction from the present content of 0.40 grams per litre would cost them FF1,500 million. Under the new directive, this will still not be obligatory. Only West Germany and Denmark apply the stricter lead content, while the United Kingdom and the Netherlands plan to do so in 1986 .

\section{Cuban science}

SOVIET scientific cooperation with Cuba will be increased under a new long-term economic and technical agreement concluded in November. The new programme foresees joint efforts in accelerating the development of Cuban science and technology, building up the material and technical research base and improving the qualifications of Cuban scientific cadres.

Arrangements will be worked out for the transfer of scientific and technical documentation to Cuba, and an educational aid programme will cover not only the training of Cuban specialists in technical schools and higher education institutes (presumably in both Cuba and the Soviet Union), but also "study attachments"' for Cuban technologists, engineers and managers at Soviet enterprises.

The new cooperation agreement is intended to complete the construction of the "material and technical base of socialism" by the end of the century. It concentrates on nine main spheres: agriculture and food processing, fuel and energy, metallurgy, machine building, electronic and electrical engineering, chemical and light industry, medical industry, construction materials and the building industry, and transport. Science and technology, formally the tenth point of the plan, seems to be seen solely in terms of the other nine.

Although the agreement is intended to strengthen the Cuban economy, there is no intention that Cuba should be selfsufficient. On the contrary, the Havana conference of Comecon leaders last summer took the idea of intra-Comecon cooperation a stage further from the existing bilateral cooperation projects.
As far as other aspects of air pollution control that were on the agenda are concerned, ministers adopted a directive setting air quality limit values for nitrogen dioxide in the air of 200 micrograms per cubic metre of air and guide values of 50 micrograms per cubic metre. The main sources of nitrogen dioxide are in fact car exhausts and factory chimneys. The standards have been strongly criticized by both the European Parliament and the European Environmental Bureau for being far too high to produce any significant reduction in the damage done to man and the environment. No progress was made on the directive limiting air pollution from large combustion plants, which would cost the United Kingdom $£ 4,000$ million, according to the UK Central Electricity Generating Board.

Meanwhile, research is to continue. Ministers agreed to grant 4 million ECU for the first year of a five-year programme to collect information and to look at different methods of measuring, among other things, environmental degradation due to acid precipitation.

Anna Lubinska

\title{
Soviet plan for joint technology
}

From now on, the intention is that the fiveyear plans of all member countries will be coordinated, leading, theoretically, to more specialization and division of labour between them.

The new agreement specifically stresses the need to "help Cuba develop the production of specific types of output primarily in the processing sectors of industry - that will ensure its broader participation in specialization and production-sharing arrangements within Comecon. Products specifically mentioned for export are sugar, fresh and processed citrus fruit, tobacco, possible new citrus products (vitamin $C$, lysine, citric acid) and medicinal plants for the pharmaceutical industry. There are less specific references to product-sharing and specialization in the electronics industry, a mutual exchange of chemical raw materials and finished products, the export of "sewn and other light industry" goods as part of a compensation deal, and, somewhat remarkably, the possible production of unspecified medical and laboratory apparatus for export to the Soviet Union.

Cuba still depends considerably on Soviet expertise and specialist advice. During an impromptu press conference last month, Dr Fidel Castro paid a glowing tribute to Soviet assistance which had provided Cuba not only with the model plant he was visiting but with oil refineries, harbour facilities and a nuclear power programme. Nevertheless, it appears that Cuba does not intend to rely solely on Soviet aid, but is prepared to shop around for expert advice within the bloc.

Vera Rich 